\title{
Pengaruh Pendidikan Kesehatan tentang Menopause terhadap Perubahan Kualitas Hidup Perempuan Klimakterik
}

\author{
Yanita Trisetiyaningsih ${ }^{1}$, Elsi Dwi Hapsari ${ }^{2}$, Shofwal Widad ${ }^{3}$ \\ ${ }^{1}$ STIKes Jenderal Ahmad Yani Yogyakarta, ${ }^{2}$ Program Studi Keperawatan, FK UGM, ${ }^{3}$ RSUP Dr. \\ Sardjito Yogyakarta \\ Email : ners_yanita@yahoo.co.id
}

\begin{abstract}
Abstrak
Perubahan fisik dan psikologis yang terjadi pada masa klimakterium akan mempengaruhi kualitas hidup perempuan. Untuk itu diperlukan proses adaptasi terhadap berbagai masalah dan perubahan selama masa klimakterium sehingga akan meningkatkan kualitas hidup perempuan klimakterik. Kurangnya pengetahuan dan akses informasi merupakan tantangan besar yang dihadapi oleh wanita menopause. Salah satu upaya yang bisa dilakukan untuk meningkatkan pengetahuan adalah melalui pemberian pendidikan kesehatan. Penelitian ini bertujuan untuk mengetahui pengaruh pendidikan kesehatan tentang menopause terhadap perubahan kualitas hidup perempuan klimakterik. Penelitian ini merupakan penelitian quasy experiment dengan rancangan pretest and posttest nonequivalent control group design. Penelitian dilakukan di Dusun Gamping Kidul Ambarketawang bulan Desember 2013-April 2014. Jumlah populasi sebanyak 271 orang. Sampel terdiri dari 44 orang kelompok intervensi dan 44 orang kelompok kontrol. Kelompok intervensi diberikan pendidikan kesehatan sebanyak 4 kali ceramah dan diskusi kelompok kecil, serta 1 kali praktik relaksasi dan senam yoga. Kelompok kontrol diberikan booklet tentang perubahan masa menopause, tanda dan gejala, nutrisi masa menopause, dan penatalaksanaan menopause. Instrumen yang digunakan adalah WHOQOL-BREF. Analisis yang digunakan adalah uji Paired t-test, Independent Samples $t$-Test dengan $\alpha 0.05$.Nilai rata-rata kualitas hidup pretest pada kelompok intervensi sebesar 51,9 dan posttest sebesar 66,5. Hasil uji paired t-test menunjukkan ada perbedaan skor kualitas hidup sebelum dan sesudah diberikan pendidikan kesehatan pada kelompok intervensi $(t=14,436, p=0,001)$. Namun tidak bermakna pada kelompok kontrol $(t=1,059, p=0,0295)$ dengan perubahan skor kualitas. Berdasarkan hasil penelitian dapat disimpulkan bahwa program pendidikan kesehatan tentang menopause dapat meningkatkan kualitas hidup perempuan selama periode klimakterium.
\end{abstract}

Kata kunci : Klimakterium, kualitas hidup, menopause, pendidikan kesehatan.

\section{Influence of Health Education about Menopause towards the Quality of Life Changes in Climacteric Women}

\begin{abstract}
Physical and psychological changes that happen at the climacterium period would influence the quality of life in climacteric women. Therefore, the adaptation process is needed to overcome problems and changes during this period so that the quality of life of climacteric women could be increased. Lack of knowledge and access to information are major challenger that were faced by menopause women. One of efforts that can be done to improve their knowledge is through health education. This study aimed to identify the influence of health education about menopause towards the quality of live changes in climacteric women. The study used quasi experiment design with pretest and posttest nonequivalent control group. The location of this study was in Gamping Kidul Ambarketawang Village in December 2013 to April 2014. The total population is 271 people. Sample consisted of 44 people in the intervention group and 44 people in the control group. The intervention group received 4 times health education and small group discussion, as well as once relaxation and Yoga. Participants in control group received a booklet about menopause, signs and symptoms, nutrition during menopause period, and management of menopause. The quality of life was measured using WHOQOL-BREF. Analysis used paired t-test, independent samples t-test with $\alpha=0.05$. The mean scores of quality of life for intervention group were 51.0 (pretest) and 66.5 (posttest). The paired t-test showed that there was a significant difference of quality of life score before and after health education in the intervention group $(t=14,436, p=0,001)$. However, there was no significant difference of quality of life in the control group $(t=1,059, p=0,0295)$. Based on this results, it can be concluded that health education program about menopause can increase quality of life of climacteric women.
\end{abstract}

Keywords: Climacterium, health education, menopause quality of life. 
Yanita Trisetiyaningsih : Pengaruh Pendidikan Kesehatan Menopause terhadap Perubahan Kulaitas Hidup

\section{Pendahuluan}

Menopause merupakan hal yang secara fisiologis akan dialami oleh seorang perempuan. Pada masa tersebut, perempuan akan mengalami berbagai perubahan baik secara fisik maupun psikologis yang akan memengaruhi kualitas hidup perempuan di masa klimakterium. Berbagai gejala dan ketidaknyamanan akan muncul pada masa menopause. Delapan puluh persen perempuan melaporkan bahwa adanya ketidaknyamanan yang terjadi saat klimakterium seperti sakit kepala, masalah seksual, takikardi, hot flushes, berkeringat dan insomnia yang secara signifikan dapat menurunkan kualitas hidup (Senba \& Matsuo, 2010). Kurangnya pengetahuan dan akses informasi merupakan tantangan besar yang dihadapi oleh wanita menghadapi menopause (Khademi, 2003).

Berdasarkan penelitian yang telah dilakukan oleh Senba \& Matsuo (2010) didapatkan hasil bahwa $22,7 \%$ perempuan klimakterik tanpa gejala, 36,4\% mengalami gejala yang sedang sehingga diperlukan modifikasi perilaku dan gaya hidup, dan 36,4\% mengalami gejala yang berat. Selain gejala klimakterik, dalam penelitian ini juga didapatkan hasil bahwa 30\% wanita klimakterik mengalami gangguan fisik, $10 \%$ mengalami gangguan psikologis dan $15 \%$ mengalami stres. Untuk itu diperlukan proses adaptasi terhadap berbagai masalah dan perubahan selama masa klimakterium sehingga mampu meningkatkan kualitas hidup perempuan klimakterik. Salah satu upaya yang bisa dilakukan oleh perawat untuk mempersiapkan perempuan menghadapi dan menjalani masa menopause adalah dengan meningkatkan pengetahuan tentang menopause sehingga bisa meningkatkan kualitas hidup melalui pemberian pendidikan kesehatan.

Pemberian pendidikan kesehatan akan membantu perempuan untuk mengembangkan pengetahuan, sikap dan perilaku dalam mengatasi perubahan dan permasalahan selama masa klimakterium sehingga mampu beradaptasi terhadap berbagai perubahan serta gejala yang terjadi pada masa tersebut. Selain itu pendidikan kesehatan merupakan salah satu strategi untuk meningkatkan perilaku dan koping perempuan dalam mengatasi gejala menopause (Rotem et al., 2005).
Penelitian serupa juga dilakukan oleh Rotem et al., (2005) yang menyatakan bahwa berpartisipasi dalam program pendidikan kesehatan yang menggabungkan antara pemberian informasi dengan pertukaran pengalaman akan meningkatkan perilaku perempuan menopause dan meningkatkan kualitas hidup.

\section{Metode Penelitian}

Penelitian ini merupakan quasy experimental dengan pretest and posttest nonequivalent control group design. Populasi dalam penelitian ini adalah semua perempuan dalam phase klimakterium, berusia antara 45 sampai 60 tahun di Dusun Gamping Kidul Ambar ketawang Gamping Sleman Yogyakarta yang berjumlah 271 orang. Berdasarkan hasil studi pendahuluhan di Dinas Kependudukan dan Catatan Sipil kabupaten Sleman didapatkan data bahwa dusun Gamping Kidul merupakan wilayah yang memiliki perempuan berusia 45-60 tahun terbanyak. Kriteria inklusi yang digunakan untuk pemilihan sampel yaitu berstatus menikah, tidak menggunakan terapi sulih hormon, tidak merokok, tidak mengalami histerektomi, tidak dilakukan ooforektomi, bisa membaca dan menulis bahasa Indonesia, bersedia ikut proses penelitian sampai akhir, BMI $<30 \mathrm{~kg} / \mathrm{m} 2$. Responden yang bekerja di unit pelayanan kesehatan, dan memiliki penyakit kronis seperti hipertensi, DM, penyakit jantung, gagal ginjal dikeluarkan dari sampel. Berdasarkan perhitungan besar sampel maka ditetapkan 44 orang untuk masing-masing kelompok.Sampel diambil berdasarkan kriteria inklusi dan eksklusi dengan teknik simple random sampling. Metode pendidikan kesehatan yang digunakan oleh peneliti adalah metode ceramah yang dimodifikasi dengan diskusi kelompok kecil, dimana setiap kelompok terdiri dari 11 orang. Kelompok intervensi diberikan intervensi berupa pendidikan kesehatan melalui metode ceramah diskusi kelompok kecil sebanyak 4 kali pertemuan dan 1 kali praktik senam yoga, sedangkan kelompok kontrol hanya diberikan booklet saja pada awal pertemuan.

Pengambilan data dilaksanakan pada bulan Desember 2013-April 2014. Pengumpulan data melalui beberapa tahap yaitu tahap pertama 
Yanita Trisetiyaningsih : Pengaruh Pendidikan Kesehatan Menopause terhadap Perubahan Kulaitas Hidup

adalah perempuan yang berusia 45-60 tahun diminta mengisi biodata untuk skrining awal lalu calon responden tersebut yang memenuhi kriteria masuk dalam tahap kedua, tahap kedua responden yang memenuhi kriteria melakukan pretest kuesioner kualitas hidup, tahap ketiga pemberian intervensi berupa pendidikan kesehatan melalui 4 kali tatap muka (ceramah dan diskusi kelompok kecil) yang diberikan oleh penyuluh dari Puskesmas Gamping I dan 1 kali praktik senam yoga oleh instruktur senam pada kelompok intervensi dan pembagian booklet pada kelompok kontrol, tahap keempat pengisian posttest kuesioner kualitas hidup yang dilaksanakan dalam selang waktu 4-5 minggu setelah pemberian intervensi. Dalam penelitian ini informasi yang diberikan antara lain tentang perubahan yang terjadi saat menopause, tanda gejala perimenopause yang mungkin muncul, kebutuhan nutrisi yang baik baik perempuan klimakterik, penatalaksanaan serta praktek senam yoga. Alat ukut yang digunakan dalam penelitian ini adalah kuesioner kualitas hidup WHOQOL-BREF dimana kuesioner ini sering dipakai oleh beberapa penelitian sebelumnya tentang kualitas hidup menopause dan cocok digunakan pada situasi penelitian dimana waktu yang digunakan sangat terbatas, dimana ketidaknyamanan atau beban yang dirasakan responden dibuat seminimal mungkin. Kuesioner ini terdiri atas empat domain yaitu fisik, psikologis, social dan lingkungan. WHOQOL-BREF terdiri dari 26 item pertanyaan; 1 item pertanyaan untuk mengukur kualitas hidup secara umum, 1 item untuk kesehatan umum, dan 24 item untuk empat domain yaitu 1) fisik terdiri dari 7 pertanyaan yang mencakup keadaan fisiologis individu berupa keluhan fisik, kebutuhan istirahat, kondisi penyakit, mobilitas dan aktivitas sehari hari, kapasitas pekerjaan; 2) psikologis terdiri dari 6 item pertanyaan yang mencakup keadaan emosional, intelektual dan kognitif individu berupa perasaan positif dan negatif, tingkat harga diri, kepercayaan individu, kemampuan untuk mengingat dan berkonsentrasi, kepuasan hidup; 3) hubungan sosial terdiri dari 3 item pertanyaan yang mencakup keadaan individu dalam memainkan peran sosial berupa interaksi interpersonal antara individu dengan orang lain, keterlibatan individu dalam melakukan kegiatan sosial, aktivitas seksual serta adanya dukungan sosial; 4) lingkungan yang terdiri dari 8 item pertanyaan. Penilaian dari keempat domain dengan menggunakan skala Likert. Kualitas hidup dikategorikan menjadi sangat jelek, cukup, baik, sangat baik, dan sempurna. Pada saat pengisian kuesioner, responden didampingi oleh kader posyandu lansia dan peneliti. Analisis yang digunakan dalam penelitian ini adalah uji Paired t-test, independent samplest-test pada $\alpha=0.05$.

\section{Hasil Penelitian}

Hasil uji homogenitas karakteristik responden antara kelompok intervensi dan kelompok kontrol didapatkan hasil bahwa tidak ada perbedaan yang bermakna pada kelompok intervensi dan kelompok kontrol dilihat dari segi karakteristik responden (tabel 1).

Berdasarkan tabel distribusi frekuensi karakteristik responden kelompok intervensi dan kelompok kontrol didapatkan hasil bahwa tidak ada perbedaan karakteristik antara kelompok intervensi dan kelompok kontrol Penilaian skor kualitas hidup perempuan klimakterik antara kelompok intervensi dan kelompok kontrol sebelum dan setelah dilakukan pendidikan kesehatan ditampilkan dalam tabel 2.

Hasil uji paired t-test menunjukkan ada perbedaan skor kualitas hidup sebelum dan sesudah diberikan pendidikan kesehatan dengan $p$-value $=0,0001$ dengan selisih skor sebesar 14,6 pada kelompok intervensi, namun tidak pada kelompok kontrol dengan nilai $\mathrm{p}$ $=0,0295$ dan $\mathrm{t}=14,436$ dengan perbedaan selisih skor kualitas hidup sebesar 0,3 (tabel $2 \& 3)$.

Berdasarkan hasil analisis Independent Samples t-test didapatkan $p$-value $<0,05$ dan nilai $\mathrm{t}>\mathrm{t}$ tabel $(1,980)$. Kesimpulannya Ho ditolak dan $\mathrm{Ha}$ diterima.Hal tersebut berarti ada perbedaan perubahan skor kualitas hidup pretest dan posttest pada domain fisik, psikologis, sosial, dan lingkungan antara kelompok intervensi dan kelompok kontrol.

\section{Pembahasan}

Hasil analisis uji beda dua kelompok 
Yanita Trisetiyaningsih : Pengaruh Pendidikan Kesehatan Menopause terhadap Perubahan Kulaitas Hidup

Tabel 1 Karakteristik Responden antara Kelompok Intervensi dan Kelompok Kontrol

\begin{tabular}{|c|c|c|c|c|c|c|}
\hline \multicolumn{2}{|c|}{ Karakteristik } & \multicolumn{2}{|c|}{$\begin{array}{c}\text { Kelompok Intervensi } \\
(\mathrm{n}=44 \text { Org) }\end{array}$} & \multicolumn{2}{|c|}{$\begin{array}{c}\text { Kelompok Kontrol } \\
(\mathrm{n}=44 \text { Org })\end{array}$} & \multirow[t]{2}{*}{ p-value } \\
\hline & & Mean \pm SD & n (\%) & Mean \pm SD & n (\%) & \\
\hline \multicolumn{2}{|c|}{ Usia Saat ini (tahun) } & $51,1 \pm 4,5$ & & $51,7 \pm 4,7$ & & 0,770 \\
\hline \multicolumn{2}{|c|}{ Usia Menarche (tahun) } & $13,6 \pm 1,6$ & & $13,3 \pm 1,4$ & & 0,314 \\
\hline \multicolumn{2}{|c|}{ Usia Menopause (tahun) } & $49,4 \pm 3,6$ & & $49,9 \pm 3,6$ & & 0,425 \\
\hline \multicolumn{7}{|l|}{ Lama Menopause } \\
\hline \multicolumn{2}{|l|}{ Belum Menopause } & & $26(59 \%)$ & & $17(38,6 \%)$ & \multirow{3}{*}{0,629} \\
\hline \multicolumn{2}{|c|}{ Menopause $<5$ tahun } & & $9(20,5 \%)$ & & $15(34,1 \%)$ & \\
\hline Menopause $\geq 5$ tah & & & $9(20,5 \%)$ & & $12(27,3 \%)$ & \\
\hline \multicolumn{7}{|c|}{ Gejala menopause } \\
\hline \multicolumn{2}{|l|}{ Tidak ada/sedikit } & & $3(6,8 \%)$ & & $5(11,4 \%)$ & \multirow{3}{*}{0,707} \\
\hline \multicolumn{2}{|l|}{ Ringan } & & $25(56,8 \%)$ & & $19(43,2 \%)$ & \\
\hline \multicolumn{2}{|l|}{ Sedang } & & $12(27,3 \%)$ & & $20(45,4 \%)$ & \\
\hline \multicolumn{2}{|l|}{ Berat } & & $4(9,1 \%)$ & & $0(0 \%)$ & \\
\hline \multicolumn{2}{|l|}{ Status pernikahan } & & & & & 0,684 \\
\hline \multicolumn{2}{|l|}{ Menikah } & & $36(81,8 \%)$ & & $35(79,5 \%)$ & \\
\hline \multicolumn{2}{|l|}{ Janda Mati } & & $7(15,9 \%)$ & & $8(18,2)$ & \\
\hline \multicolumn{2}{|l|}{ Cerai } & & $1(2,3 \%)$ & & $1(2,3 \%)$ & \\
\hline \multicolumn{2}{|l|}{ Pendidikan } & & & & & 0,757 \\
\hline \multicolumn{2}{|l|}{ Rendah $(\leq \mathrm{SD})$} & & $19(43,2 \%)$ & & $15(34,1)$ & \\
\hline \multicolumn{2}{|c|}{ Sedang (SMP-SMA) } & & $23(52,3 \%)$ & & $25(56,8 \%)$ & \\
\hline \multicolumn{2}{|c|}{ Tinggi ( $\geq$ Diplola/Strata 1$)$} & & $2(4,5 \%)$ & & $4(9,1 \%)$ & \\
\hline \multicolumn{2}{|c|}{ Penghasilan } & & & & & 0,766 \\
\hline $\begin{array}{l}\text { Lebih dari } \\
(\geq 1.127 .000)\end{array}$ & UMK & & $22(50 \%)$ & & $23(52,3 \%)$ & \\
\hline $\begin{array}{l}\text { Kurang } \\
(<1,127.000)\end{array}$ dari & UMK & & $22(50 \%)$ & & $21(47,7 \%)$ & \\
\hline Pekerjaan & & & & & & 0,130 \\
\hline Bekerja & & & $17(38,6 \%)$ & & $22(50 \%)$ & \\
\hline Tidak Bekerja & & & $27(61,4 \%)$ & & $22(50 \%)$ & \\
\hline Asuransi Kesehat & & & & & & 0,405 \\
\hline Punya & & & $19(43,2 \%)$ & & $27(61,4 \%)$ & \\
\hline Tidak Punya & & & $25(56,8 \%)$ & & $17(38,6 \%)$ & \\
\hline Paritas & & & & & & 0,289 \\
\hline Nullipara (anak hid & & & $3(6,8 \%)$ & & $1(2,3 \%)$ & \\
\hline Primipara (anak hi & & & $5(11,4 \%)$ & & $4(9,1 \%)$ & \\
\hline Multipara (anak hi & $\geq 2)$ & & $36(81,8 \%)$ & & $39(88,6 \%)$ & \\
\hline Kualitas Hidup Pr & & & & & & 0,185 \\
\hline Cukup (25-49) & & & $16(36,4 \%)$ & & $13(29,5 \%)$ & \\
\hline Baik (50-74) & & & $28(63,6 \%)$ & & $31(70,5 \%)$ & \\
\hline
\end{tabular}


Yanita Trisetiyaningsih : Pengaruh Pendidikan Kesehatan Menopause terhadap Perubahan Kulaitas Hidup

Tabel 2 Hasil Penilaian Kualitas Hidup Perempuan Klimakterik Kelompok Intervensi dan Kelompok Kontrol di Dusun Gamping Kidul Ambarketawang Gamping Sleman Yogyakarta Tahun 2016 (N=88)

\begin{tabular}{lccccc}
\hline \multicolumn{1}{c}{ Variabel } & n & Minimum & Maximum & Mean & SD \\
\hline $\begin{array}{l}\text { Kelompok } \\
\text { Intervensi }\end{array}$ & & & & & \\
Pretest & 44 & 36 & 64 & 51,9 & 6,8 \\
Posttest & 44 & 61 & 81 & 66,5 & 4,4 \\
Gained Score & & & & 14,6 & \\
Kelompok & & & & & \\
Kontrol & 44 & 39 & 65 & 53,7 & 6,4 \\
Pretest & 44 & 41 & 64 & 54 & 6,1 \\
Posttest & & & & 0,3 & \\
Gained Score & & & &
\end{tabular}

Tabel 3 Hasil analisis Paired Samples T-test Kualitas Hidup pada Kelompok Intervensi dan Kelompok Kontrol

\begin{tabular}{lcccccc}
\hline $\begin{array}{l}\text { Skor Kualitas Hidup } \\
\text { Pretest-Posttest }\end{array}$ & Mean & \multicolumn{2}{c}{$\mathbf{9 5 \%}$ CI } & t & df & Sig \\
\cline { 3 - 4 } & & Lower & Upper & & & \\
\hline Kelompok Intervensi & $-14,545$ & $-16,577$ & $-12,513$ & $-14,436$ & 43 & 0,000 \\
Kelompok Kontrol & $-0,295$ & $-0,858$ & $-0,267$ & $-1,059$ & 43 & 0,295 \\
\hline
\end{tabular}

Tabel 4 Hasil Uji Beda Perubahan Skor Kualitas Hidup Pretest dan Posttest pada Dua Kelompok Tidak Berpasangan (Independent Samples t-test)

\begin{tabular}{|c|c|c|c|c|c|}
\hline \multirow{2}{*}{$\begin{array}{c}\text { Variabel } \\
\text { Kualitas Hidup }\end{array}$} & \multirow[t]{2}{*}{$\mathbf{t}$} & \multirow[t]{2}{*}{ Sig (2-tailed) } & \multirow{2}{*}{$\begin{array}{c}\text { Mean } \\
\text { Difference }\end{array}$} & \multicolumn{2}{|c|}{$95 \% \mathrm{CI}$} \\
\hline & & & & Lower & Upper \\
\hline Domain Fisik & 9,681 & 0,000 & 15,182 & 18,299 & 12,064 \\
\hline Domain Psikologis & 8,734 & 0,000 & 13,250 & 16,266 & 10,234 \\
\hline Domain Sosial & 7,464 & 0,000 & 13,023 & 16,491 & 9,554 \\
\hline Domain Lingkungan & 4,743 & 0,000 & 8,614 & 12,224 & 5,004 \\
\hline
\end{tabular}

Pendidikan kesehatan merupakan suatu proses untuk menyadarkan, meningkatkan pengetahuan dan merubah perilaku masyarakat tentang kesehatan. Pendidikan kesehatan bertujuan agar masyarakat menyadari dan mengetahui cara memelihara kesehatan, menghindari atau mencegah dari hal hal yang merugikan kesehatan serta bagaimana mencari pengobatan yang tepat (Notoatmojo, 2009).

Pendidikan kesehatan yang dilakukan dalam penelitian ini mengacu pada model pendidikan kesehatan PROCEDE-PRECEDE yang merupakan pendidikan kesehatan berbasis masalah. Masalah diidentifikasi melalui proses diskusi kelompok terarah (FGD/Focus
Group Discussion) dan penyebaran kuesioner terkait dengan pengetahuan responden tentang menopause. Adapun masalah yang ditemukan antara lain kurangnya pengetahuan perempuan klimakterik terkait dengan menopause yang meliputi perubahan selama menopause, gejala yang muncul, kebutuhan nutrisi bagi perempuan klimakterik, penatalaksanaan menopause serta latihan/aktivitas yang perlu dan baik dilakukan saat menopause.

Menurut teori PROCEDE-PRECEDE oleh Green (1980) dalam Notoatmodjo (2010) komponen pendidikan kesehatan terbagi dalam 3 yaitu faktor predisposisi berupa pengetahuan, sikap, nilai, persepsi; faktor 
Yanita Trisetiyaningsih : Pengaruh Pendidikan Kesehatan Menopause terhadap Perubahan Kulaitas Hidup

pemungkin berupa ketersediaan sumberdaya, keterjangkauan rujukan, ketrampilan petugas; faktor penguat berupa sikap dan perilaku. Dengan pemberian pendidikan kesehatan pada penelitian ini diharapkan dapat memperbaiki dan meningkatkan ketiga komponen tersebut sehingga akan berdampak pada menurunnya masalah kesehatan berupa penurunan gejala perimenopause serta meningkatkan kemampuan beradaptasi terhadap perubahan yang muncul saat menopause. Penurunan masalah kesehatan tersebut akhirnya akan memperbaiki kualitas hidup perempuan klimakterik.

Informasi yang benar mengenai menopause akan membantu perempuan klimakterik dalam melakukan adaptasi terhadap perubahan yang terjadi serta tanda gejala yang mungkin muncul saat menopause, mampu memenuhi pola hidup sehat dengan nutrisi yang tepat, serta mampu mencari bantuan perawatan kesehatan jika terjadi masalah kesehatan. Sedangkan latihan senam yoga dilakukan untuk memberikan ketenangan dan mengurangi stres serta depresi pada perempuan klimakterik dalam menghadapi masa menopause..

Pendidikan kesehatan dalam penelitian ini dilakukan melalui metode ceramah dan diskusi kelompok kecil serta latihan senam yoga. Kombinasi lebih dari satu metode akan lebih efektif dibandingkan dengan hanya satu metode saja. Hasil penelitian yang dilakukan oleh Ueda et al (2009) menyatakan bahwa program pendidikan yang menggabungkan teori dan praktik lebih efektif. Hal ini sejalan dengan teori Frith (2000) dalam Alerston \& Davies (2010) yang menyatakan bahwa metode diskusi kelompok dapat menyediakan informasi dan pengalaman yang baik.

Pemberian pendidikan kesehatan akan membantu perempuan untuk meningkatkan pengetahuan, sikap dan perilaku. Salah satu faktor pendukung dalam peningkatan pengetahuan adalah tingkat pendidikan. Dalam penelitian ini $52,3 \%$ responden mempunyai tingkat pendidikan sedang (SMP-SMA), dan $4,5 \%$ mempunyai tingkat pendidikan tinggi. Tingkat pendidikan yang semakin tinggi akan semakin mempermudah dalam menerima informasi yang diberikan. Dalam Notoatmojo (2010) bahwa pendidikan yang pernah ditempuh sesorang merupakan faktor yang akan mendukung kemampuan seseorang untuk menerima informasi, semakin tinggi tingkat pendidikan seseorang maka semakin luas cara pandang dan cara pikir dalam menghadapi suatu permasalahan yang terjadi di sekitarnya. Nugraheny (2012) menyatakan bahwa ada pengaruh pemberian pendidikan kesehatan terhadap pengetahuan ibu tentang menopause. Pengetahuan yang lebih baik akan memberikan pengaruh yang besar terhadap sikap yang positif dalam menghadapi menopause. Sikap yang positif dalam menjalani menopause dengan berbagai gejala dan keluhan yang terjadi akan membantu perempuan klimakterik menjalani masa menopause dengan bahagia sehingga mampu berperilaku yang baik dan mampu meningkatkan derajat kesehatan dirinya. Derajat kesehatan yang baik akan berdampak pada kualitas hidup yang baik pula. Fitriani (2011) menyatakan indikator dalam mencapai keberhasilan suatu proses pendidikan kesehatan adalah adanya peningkatan pengetahuan dan sikap individu yang diaplikasikan dalam perilaku sehari hari. Penelitian serupa juga dilakukan oleh Rotem et al., (2005) yang menyatakan bahwa berpartisipasi dalam program pendidikan kesehatan yang menggabungkan antara pemberian informasi dengan pertukaran pengalaman pada kognitif, emosi dan sosial akan meningkatkan perilaku perempuan menopause dan meningkatkan kualitas hidup. Peningkatan skor kualitas hidup pada kelompok intervensi juga dipengaruhi oleh jeda waktu pengukuran kualitas hidup antara sebelum dan sesudah diberikan pendidikan kesehatan. Jeda waktu yang diperlukan dalam menerima, mengendapkan informasi sampai dengan mengaplikasikan sangat menentukan keberhasilan peningkatan kualitas hidup. Dalam penelitian ini, kualitas hidup posttest diukur setelah 4-5 minggu pemberian pendidikan kesehatan. Jeda waktu diperlukan untuk melakukan proses adopsi perilaku.

Menurut teori berubah (adopsi) Roger dan Shoamaker (1971) dalam Marhaeni (2009), proses adopsi inovasi merupakan proses kejiwaan/mental yang terjadi dalam diri seseorang pada saat menghadapi suatu inovasi. Adopsi terjadi proses penerapan ide baru sejak diketahui atau didengar sampai diterapkan. Proses perubahan perilaku ditentukan oleh jarak dan waktu. Proses adopsi melalui 5 tahapan perubahan perilaku 
Yanita Trisetiyaningsih : Pengaruh Pendidikan Kesehatan Menopause terhadap Perubahan Kulaitas Hidup

yaitu: (1) awareness (tahu dan sadar) pertama kali mendapat ide dan praktek baru; (2) interest (minat) mencari rintisan informasi; (3) evaluation (evaluasi) menilai manfaat inovasi yaitu penilaian tentang untung rugi suatu inovasi bila melaksanakan; (4) trial (mencoba) dan (5) adoption (adopsi) menerapkan perubahan dari ide baru yang diterima. Dalam penelitian ini hasil penerimaan ide baru diamati dari adanya perubahan skor kualitas hidup.

Hasil analisis uji beda dua kelompok berpasangan (paired samples t-test) pada kelompok intervensi menyatakan bahwa pendidikan kesehatan dapat meningkatkan kualitas hidup perempuan klimakterik. Hal ini dibuktikan dengan adanya peningkatan skor kualitas hidup posttest pada kelompok intervensi pada 44 orang $(100 \%)$ dengan skor peningkatan minimun 5 dan maksimum 30.Pada kelompok intervensi pendidikan kesehatan mampu meningkatkan skor kualitas hidup sebesar 14,6.

Menurut penelitian Fitriana (2011), kualitas hidup perempuan klimakterik yang baik dapat dilihat dari subyek yang mampu mengenali diri sendiri (mampu menyadari kekurangan dan kelebihan yang dimiliki), mampu beradaptasi dengan kondisi menopause yang sedang dialaminya, dapat merasakan penderitaan orang lain (memberikan solusi terbaik pada orang lain), mempunyai perasaan kasih sayang (semua orang terdekat memberikan perhatian), subyek bersikap optimis (yakin dapat mengerjakan pekerjaan dengan baik), dan mampu mengembangkan sikap empati.

Hasil penelitian ini mendukung penelitian yang dilakukan oleh Ueda et al (2009) menyatakan bahwa program pendidikan kesehatan berpengaruh positif terhadap kualitas hidup.Hasil penelitian Hunter dan O'dea (1999) juga mendapatkan bahwa perempuan yang mendapatkan program pendidikan tentang menopause mempunyai pengetahuan dan kebiasaan hidup sehat yang lebih baik. Selain itu $65 \%$ melaporkan bahwa program pendidikan ini membantu mereka mengatasi masalah emosional selama menopause.

Penelitian ini juga mendukung penelitian yang dilakukan oleh Senba dan Matsuo (2009) bahwa pendidikan kesehatan mempunyai efek positif pada perempuan yang mengalami klimakterium dalam hal peningkatan status kesehatan, perubahan perilaku kognitif dan aktivitas sistem syaraf pusat. Selain itu pendidikan kesehatan juga dapat meningkatkan pengetahuan dan mengembangkan kemampuan perawatan kesehatan personal.

Hasil analisis paired samples t-test pada kelompok kontrol menunjukkan tidak ada perbedaan yang bermakna skor kualitas hidup antara pretest dan posttest. Hal ini dibuktikan dengan data bahwa dari 44 orang dalam kelompok kontrol, 11 orang $(25 \%)$ mengalami penurunan skor kualitas hidup posttest, 12 orang $(27,3 \%)$ mempunyai skor kualitas hidup posttest yang tidak berubah/tetap, dan 21 orang $(47,7 \%)$ mengalami kenaikan skor kualitas hidup posttest. Adapun perubahan skor kualitas hidup posttest pada kelompok kontrol minimal sebesar $-4,8$ dan maksimal= 3,2 .

Kelompok kontrol hanya mengalami peningkatan skor kualitas hidup sebesar 0,3 . Hal ini terjadi karena responden hanya mendapatkan informasi dari booklet saja. Walaupun responden mendapatkan informasi dari booklet namun tidak cukup dapat meningkatkan kualitas hidup karena informasi hanya bersifat tertulis dan monoton sehingga kurang menarik untuk dibaca. Hovland dan Weiss (1951) dalam Ramdhani (2008) menyebutkan bahwa informasi yang disampaikan oleh seseorang yang ahli di bidangnya secara langsung dan secara sukarela meluangkan perhatiannya, maka pesan yang disampaikan akan lebih menarik dan mudah dipahami oleh responden.

Berdasarkan data tingkat pendidikan pada kelompok kontrol mempunyai tingkat pendidikan sedang $(56,8 \%)$ dan tinggi sebanyak 9,1\%. Namun pendidikan yang sedang dan tinggi tidak menunjukkan adanya peningkatan skor kualitas hidup yang signifikan. Hal ini dikarenakan pada kelompok kontrol tidak mendapatkan informasi langsung dari tenaga kesehatan atau orang yang ahli di bidang menopause, melainkan hanya membaca booklet saja.

Hasil pada analisis Independent Samples t-test menunjukkan hasil yang signifikan, artinya bahwa kualitas hidup perempuan klimakterik pada kelompok intervensi lebih baik dibandingkan dengan kelompok kontrol. 
Yanita Trisetiyaningsih : Pengaruh Pendidikan Kesehatan Menopause terhadap Perubahan Kulaitas Hidup

Hal ini terjadi karena pendidikan kesehatan tentang menopause pada kelompok intervensi dilakukan dengan metode dan media yang tepat dan sesuai bagi perempuan klimakterik.

\section{Simpulan}

Ada perubahan skor kualitas hidup antara pretest dan posttest pada kelompok intervensi dan kelompok kontrol. Ada perbedaan skor kualitas hidup perempuan klimakterik sebelum (pretest) dan setelah diberikan pendidikan kesehatan (posttest) tentang menopause pada kelompok intervensi. Tidak ada perbedaan kualitas hidup perempuan klimakterik pretest dan posttest pada kelompok kontrol.Ada perbedaan perubahan skor kualitas hidup perempuan klimakterik pretest dan posttest pada domain fisik, psikologis, sosial, dan lingkungan antara kelompok intervensi dan kelompok kontrol. Jadi hasil penelitian ini sejalan dengan penelitian sebelumnya bahwa ada pengaruh pendidikan kesehatan terhadap kualitas hidup perempuan klimakterik.

Bagi perempuan klimakterik diharapkan lebih meningkatkan upaya upaya untuk mengikuti penyuluhan ataupun mencari informasi terkait dengan permasalahan yang terjadi saat masa menopause baik melalui media massa maupun tenaga kesehatan di Puskesmas.Bagi Puskesmas dapat meningkatkan frekuensi pemberian pendidikan kesehatan.

\section{Daftar Pustaka}

Allerston, S., \& Davies, G. (2010). Sex education is a much about personal relationships as biological understanding. United Kingdom: Nelson Thornes Ltd.

Baziad, A.M. (2003). Endokrinologi ginekologi. Jakarta: Penerbit Media Aeskulapius Fakultas Kedokteran Universitas Indonesia.

Fitriani, S. (2011). Promotion of health. Silva, A.R., \& Tanaka. (2013). ACD factors

\section{London: Graha Science.}

Hunter, M., \& O’Dea, I. (1999). An evaluation of health education intervention for mid-aged women: five year follow-up og effect uponj knowledge, impact of menopause and health. Patient education and counseling, 38, 249255.

Kalarhoudi, M.A., Taebi, M., Sadat, Z., \& Saberi, F. (2011) Assessment of quality of life in menopausal periods: A population study in Kashan, Iran. Iranian Red Crescent Med J., 13 (11), 811-817.

Khademi, S. (2003). Comparing the attitudes of urban and rural iranian women toward menopause. Maturity, 46(2), 113-21.

Li, L., et al. (2012). Factors associated with the age of the natural menopause and menopausal symptoms in Chinese women. Maturity, 73, 354-360.

Marhaeni, F. (2009). Sciences communication theory and practice. London: Graha Science.

Notoatmodjo, S. (2010). Theory and application of health promotion. Jakarta: Rineka Copyright.

Nugraheny, D.H. (2008). Post fracture patient quality of life post-earthquake in Jetis Bantul, Yogyakarta (Thesis). Nursing Science Faculty of Medicine, University of Gadjah Mada.

Ramdhani, N. (2008). Formation and attitude change. London: Faculty of Psychology.

Rotem, M., Kushnir, T., Levine, M., \& Ebrenfeld. (2005). A psycho-educational program for improvement of women's attitudes and coping with menopause symptoms. JONN, 34(2), 233-40.

Senba, N., \& Matsuo, H.. (2010). Effects of a health education program on climacteric women. Climacteric, 13, 561-569. 
Yanita Trisetiyaningsih : Pengaruh Pendidikan Kesehatan Menopause terhadap Perubahan Kulaitas Hidup

associated with severity of menopausal Ueda, M., Matsuda, M., Okano, K., \& symptoms in middle-aged Brazilian women Suenaga, H. (2009). Longitudinal study og a from the western Brazilian Amazon. Maturity health education program for Japanese women $76,64-69$. in menopause. Nursing and Health Sciences. $11,114-119$. 